\title{
ENZYME ACTIVITY OF SPERMATOZOA FROM THE DUCTUS DEFERENS OF INBRED MICE
}

\author{
R. S. MATHUR* AND R. A. BEATTY $\dagger$ \\ Department of Genetics, University of Edinburgh
}

(Received 26th Fune 1973)

\begin{abstract}
Summary. Quantitative estimations indicated the presence of DOPA oxidase (DOPA-OX), lactic dehydrogenase (LDH), malic dehydrogenase $(\mathrm{MDH})$ and leucine aminopeptidase (LAP) in unwashed spermatozoa from the ductus deferentes of three inbred strains of mice (CBA, JBT and C57). Variations in enzyme activity attributable to a combination of age and strain effects were highly significant for all enzymes except MDH. There was one highly significant strain-specific difference, spermatozoa of $\mathrm{C} 57$ mice having about $2 \frac{1}{2}$ times the LDH activity of spermatozoa from CBA mice of comparable age. A-strain (albino) mice did not react for DOPA-OX whereas the three pigmented strains reacted positively. Strains which did not differ in mean enzyme activity were: CBA, C57, JBT (DOPA-OX); CBA, JBT (MDH).
\end{abstract}

\section{INTRODUCTION}

Inbred strains of mice differ characteristically in the dimensions of their spermatozoa (see Braden, 1959; Beatty \& Sharma, 1960; Williams, Beatty \& Burgoyne, 1970) whereas the age of the male and other non-genetic factors have little or no effect (see Beatty, 1970). Advancing age was associated with a pronounced rise in the proportion of spermatozoa with loose or missing acrosomes (Beatty \& Mukherjee, 1963) but there was again little or no effect on dimensions. Parallel evidence of age and strain effects on the enzymes of mouse spermatozoa appears to be lacking. Our first objective was to detect quantitatively enzymes that occur regularly in mice irrespective of strain or age. The second objective was to detect differences in enzyme activity attributable to the combined effect of age and strain differences. As a basis for further studies on the genetic determinants of the sperm phenotype, a third objective was to detect strain-specific effects on enzyme activity (i.e. differences between strains in their enzyme activity).

\section{MATERIALS AND METHODS}

\section{Preparation of sperm suspensions}

Spermatozoa were recovered from males of the inbred strains $\mathrm{CBA} / \mathrm{Fa}$,

* Present address: Cell Biology Section, Department of Zoology, University of Rajasthan, Jaipur 4, India.

$\dagger$ Agricultural Research Council Unit of Animal Genetics. 
$\mathrm{C} 57 \mathrm{BL} / \mathrm{Fa}, \mathrm{JBT} / \mathrm{Jd}$ and $\mathrm{A} / \mathrm{Fa}$, all maintained in this Department. The animals were killed by an overdose of ether. Spermatozoa expressed from the excised ductus deferentes of each male were suspended in $1.0 \mathrm{ml}$ of $0.85 \%$ sodium chloride. The sperm concentration (averaging $2 \times 10^{6} / \mathrm{ml}$ ) was determined after haemocytometer counts on a portion of each suspension diluted tenfold with $5 \%$ neutral formalin in $0.85 \%$ sodium chloride. Each suspension was homogenized manually for $5 \mathrm{~min}$ in a smooth-walled glass tube with a groundglass pestle.

\section{General procedure for assaying enzyme activity}

All the suspension obtained from a single animal was required to assay a single enzyme. It was converted into a reaction mixture by the specific methods described below. The course of the reaction (at constant temperature) was followed by taking absorbancy readings on aliquots of the reaction mixture at successive time intervals with a Beckman DB u.v. spectrophotometer with standard silica cells of $10-\mathrm{mm}$ optical path. After subtracting control readings according to the technique, the net average change in absorbancy in unit time was measured by calculating the regression coefficient in the regression of net absorbancy on time (the relationship was satisfactorily linear). Each coefficient was multiplied by $\mathrm{K} \overline{\mathrm{C}} / \mathrm{C}$, where $\mathrm{K}$ was an arbitrary constant particular to each enzyme, $\overline{\mathrm{C}}$ was the mean sperm concentration for all the males of a given enzyme series, and $\mathrm{C}$ was the sperm concentration of the particular suspension. The resulting figures for each suspension are given in Table 1, each being an estimate in arbitrary absorbancy units (linearly related to the readings of the spectrophotometer) of enzyme activity (= change in net absorbancy in unit time per unit number of spermatozoa). The statistical weighting of each enzyme activity figure in each enzyme series may be taken as unity, since the regression coefficients had small standard errors and variations in $\mathrm{G}$ were small.

\section{Specific assay techniques}

Techniques followed those of the 'Worthington Manual' (1969). They are outlined below in relation to our particular procedures.

$D O P A$-oxidase. Reaction mixtures at $25^{\circ} \mathrm{C}$ containing $0.1 \mathrm{ml}$ sperm suspension were read against controls lacking spermatozoa. A reading of spermatozoa in distilled water against distilled water was subtracted. The 'Worthington Manual' procedure for tyrosinase was followed, but with readings every $10 \mathrm{~min}$ for $1 \mathrm{hr}$, and with dihydroxyphenylalanine substituted for tyrosine.

Lactic dehydrogenase. Reaction mixtures at $25^{\circ} \mathrm{C}$ containing $0.1 \mathrm{ml}$ sperm suspension were read against controls lacking spermatozoa. A reading of spermatozoa in distilled water against distilled water was subtracted. Readings were taken every $30 \mathrm{sec}$ for $3 \mathrm{~min}$.

Malic dehydrogenase. Each reaction mixture at $25^{\circ} \mathrm{C}$ contained $0 \cdot 1 \mathrm{ml}$ sperm suspension and was read against a control lacking substrate. A reading of substrate against water was subtracted. Readings were taken every $15 \mathrm{sec}$ for $2 \mathrm{~min}$.

Leucine aminopeptidase. Each reaction mixture, containing $0.1 \mathrm{ml}$ sperm suspension, was activated for $3 \mathrm{hr}$ at $40^{\circ} \mathrm{C}$ in a mixture of $0.025 \mathrm{M}$-manganese 
chloride and tris buffer ( $\mathrm{pH} 8.5$ ). After activation, 0.125 $\mathrm{M}$-l-leucinamide ( $\mathrm{pH} 8.5$ ) was added to the 'test' and $0.0625 \mathrm{M}$-leucine ( $\mathrm{pH} \mathrm{8.5)}$ ) to a control. 'Test' was read against control. Readings were taken every $30 \mathrm{sec}$ for $3 \mathrm{~min}$.

\section{RESULTS}

Evidence of enzyme activity

With the unique exception of the DOPA-oxidase (DOPA-OX) readings for A-strain mice, all males of all strains gave a positive reading for all enzymes (Table 1). The Group means all differ significantly from zero, being greatly in

Table 1. Enzyme activity in the spermatozoa of four groups of mice of inbred strains

\begin{tabular}{|c|c|c|c|c|c|c|c|c|c|}
\hline \multirow{3}{*}{ Group } & \multirow{3}{*}{$\begin{array}{l}\text { Mouse } \\
\text { strain }\end{array}$} & \multicolumn{8}{|c|}{ Enzyme activity and mouse age } \\
\hline & & \multicolumn{2}{|c|}{$D O P A-O X$} & \multicolumn{2}{|c|}{$L D H$} & \multicolumn{2}{|c|}{$M D H$} & \multicolumn{2}{|c|}{$L A P$} \\
\hline & & $E$ & $A$ & $E$ & $A$ & $E$ & $A$ & $E$ & $A$ \\
\hline \multirow[t]{2}{*}{ I } & GBA & $\begin{array}{l}1.23 \\
1.04 \\
1.45 \\
0.92\end{array}$ & 95 & $\begin{array}{l}1 \cdot 79 \\
0.97 \\
1.30 \\
1.42\end{array}$ & 54 & $\begin{array}{l}6 \cdot 22 \\
7 \cdot 85 \\
5 \cdot 63 \\
5 \cdot 74\end{array}$ & 48 & $\begin{array}{l}2 \cdot 53 \\
2 \cdot 79 \\
2 \cdot 48 \\
2 \cdot 79\end{array}$ & 57 \\
\hline & $\tilde{\mathbf{E}}$ & $1 \cdot 16$ & & $1 \cdot 37$ & & $6 \cdot 36$ & & $2 \cdot 65$ & \\
\hline \multirow[t]{2}{*}{ II } & JBT & $\begin{array}{l}1.57 \\
0.66 \\
1.74 \\
1.21\end{array}$ & 86 & $\begin{array}{l}2 \cdot 29 \\
2 \cdot 61 \\
1 \cdot 43 \\
3 \cdot 29\end{array}$ & 89 & $\begin{array}{l}4 \cdot 66 \\
3.51 \\
5 \cdot 50 \\
5 \cdot 40\end{array}$ & 45 & $\begin{array}{l}1.93 \\
2.10 \\
1.65 \\
1.85\end{array}$ & 124 \\
\hline & $\overline{\mathbf{E}}$ & $1 \cdot 30$ & & $2 \cdot 40$ & & $4 \cdot 77$ & & $1 \cdot 88$ & \\
\hline \multirow[t]{2}{*}{ III } & C.57 & $\begin{array}{l}1.55 \\
0.68 \\
1.27 \\
1.85\end{array}$ & 95 & $\begin{array}{l}4 \cdot 09 \\
3 \cdot 41 \\
3 \cdot 08 \\
2 \cdot 59\end{array}$ & 51 & $\begin{array}{l}6 \cdot 48 \\
7 \cdot 85 \\
3 \cdot 83 \\
7 \cdot 48\end{array}$ & 76 & $\begin{array}{l}2 \cdot 90 \\
2 \cdot 66 \\
2 \cdot 50 \\
2 \cdot 34\end{array}$ & 74 \\
\hline & $\overline{\mathrm{E}}$ & $1 \cdot 34$ & & $3 \cdot 29$ & & $6 \cdot 41$ & & $2 \cdot 60$ & \\
\hline IV & $\overline{\mathbf{E}}$ & $\begin{array}{r}-0.28 \\
0.07 \\
-0.33 \\
-0.38 \\
-0.23\end{array}$ & 163 & & & & & & \\
\hline \multirow{2}{*}{\multicolumn{2}{|c|}{$\begin{array}{l}\text { S.E. [d.f.] } \\
\text { per Group mean } \\
\text { Significance } \\
(P) \text { of overall } \\
\text { differences } \\
\text { between } \\
\text { Group means }\end{array}$}} & \multicolumn{2}{|c|}{ $\pm 0 \cdot 19_{[12]}$} & \multicolumn{2}{|c|}{ $\pm 0.30_{[9]}$} & \multicolumn{2}{|c|}{ $\pm 0 \cdot 66_{[9]}$} & \multicolumn{2}{|c|}{ $\pm 0 \cdot 10_{[9]}$} \\
\hline & & \multicolumn{2}{|l|}{$<0.005$} & \multicolumn{2}{|c|}{$0.01-0.005$} & \multicolumn{2}{|c|}{$0 \cdot 25-0 \cdot 10$} & \multicolumn{2}{|c|}{$<0 \cdot 005$} \\
\hline
\end{tabular}

Enzyme activity (E) in four males per Group, with Group means of activity $(\bar{E})$, and male age $\bar{A}$ in days. Standard errors (S.E.) are based on the within-Group variance. Deviations of Group means from zero may be considered significant if they exceed twice the S.E.; differences between Group means if they exceed three times the S.E. Significance levels are from analyses of variance (which can be reconstituted from the data), with partitioning of variance into 'between Group means' and 'between males within Group means'. 
excess of their standard errors (except, once again, for the near-zero DOPA-OX activity of the A-strain mice of Group IV).

\section{Evidence of combined effects of age and strain}

The four Groups into which the mice are classified in Table 1 differ from one another in two ways: (a) each Group represents a different strain, and (b) the mean age of males differs between Groups. Limitations in the availability of material had forced us to use mice of relatively uniform age within Groups (the average standard deviation was only 12 days), while large differences existed between the mean ages of certain Groups. This sampling prevented the use of covariance analysis intended to disentangle the separate effects of strain and age. Overall differences between Group means can, however, be tested by a simple analysis of variance. A significant difference between Group means would indicate a collective effect of age and strain, i.e. activity is affected by either age or strain, or by both. As shown in the lower line of Table 1, all overall Group differences are significant for all enzymes except malic dehydrogenase $(\mathrm{MDH})$.

\section{Evidence of strain-specific effects}

Although we cannot in general disentangle the independent effects of age and strain, we can still compare certain strains that happen to be of virtually the same age and in this way obtain evidence of strain-specific effects on enzyme activity.

DOPA-oxidase. From the Group means and standard errors, it is clear that the CBA, C57 and JBT strains react positively but do not differ significantly from one another. (This was confirmed by an overall test based on analysis of variance.) Since the three strains are of comparable age, we conclude that no demonstrable strain differences exist between them. The A-strain, however, has a virtually zero DOPA-OX activity, significantly different from each of the other strains; this is discussed below.

Lactic dehydrogenase. Mice of the C57 strain have about $2 \frac{1}{2}$ times the LDH activity of CBA mice, the difference being highly significant. Since the two strains were of virtually the same age, we conclude that a strain-specific difference exists.

Malic dehydrogenase. Mice of the CBA and JBT strains, of virtually the same age, do not differ significantly in $\mathrm{MDH}$ activity, and we conclude that no strainspecific difference exists.

Leucine aminopeptidase. Age and strain effects cannot be disentangled, but we note as no more than a pointer for future work that there is some appearance of a negative correlation between age and LAP activity.

\section{DISCUSSION}

Positive reactions have been obtained for DOPA-OX, LDH, MDH and LAP in unwashed spermatozoa from the ductus deferens of mice of various ages and strains, i.e. in material that is composed primarily of spermatozoa, with a little fluid and a small number of contaminating cells present. Prior histochemical 
studies on the same strains by Mathur (1970) show that at least part of the enzyme activity comes from the spermatozoa themselves since DOPA-OX has been identified in the mid-piece and tail, and LAP in the tail, while LDH and $\mathrm{MDH}$ have given intense reactions in the mid-piece.

Detection of strain and age effects was carried out in two stages. In the first stage, a combined age and strain effect was assessed, i.e. an effect which must be caused by age differences, or by strain differences, or by both. A highly significant combined effect existed for DOPA-OX, LDH and LAP, but there was no significant combined effect for MDH. Partitioning of the combined effect into separate age- and strain-specific effects must in general await further work. A limited number of strain-specific effects could, however, be assessed by comparing the enzyme activity of strains that happened to be of virtually the same age. Some negative results were that the following strains did not differ significantly in activity: CBA, C57, JBT (DOPA-OX); CBA, JBT (MDH). A positive result was that DOPA-OX activity in the three pigmented strains was significantly higher than in the A-strain, the activity of the latter strain being close to zero. The A-strain mice were particularly old and we cannot say formally if their zero activity is strain-specific or due to their unusual age. Since A-strain was the only albino strain employed, however, and zero activity would be expected on a priori grounds, there is a strong presumption that a strain-specific effect existed. A low DOPA-OX activity has been reported in washed ejaculated spermatozoa of the albino rabbit by Beatty (1956). Finally, G57 mice had about $2 \frac{1}{2}$ times the LDH activity of CBA mice of comparable age, the difference being highly significant.

\section{ACKNOWLEDGMENTS}

One of us (R.S.M.) is grateful to the University of Edinburgh for a Senior Research Fellowship, supported by a Ford Foundation Grant in aid of research by $\operatorname{Dr}$ R. A. Beatty; to the Commonwealth Foundation, London, for a travel grant; to the University of Rajasthan, Jaipur, India, for study leave; and to Professor D. S. Falconer for the hospitality of the Department of Genetics. We are grateful to Mr V. J. Coulter for technical assistance, and to Miss H. I. Macrae for supplying the mice.

\section{REFERENCES}

Beatty, R. A. (1956) Melanizing activity of semen from rabbit males of different genotype. Proc. $R$. phys. Soc. Edinb. 25, 39.

Beatty, R. A. (1970) The genetics of the mammalian gamete. Biol. Rev. 45, 73.

Beatty, R. A. \& Mukherjee, D. P. (1963) Spermatozoan characteristics in mice of different ages. $\mathcal{F}$. Reprod. Fert. 6, 261.

Beatty, R. A. \& Sharma, K. N. (1960) Genetics of gametes. III. Strain differences in spermatozoa from eight inbred strains of mice. Proc. R. Soc. Edinb. B, 68, 25.

Braden, A. W. H. (1959) Strain differences in the morphology of the gametes of the mouse. Aust. $\mathcal{F}$. biol. Sci. 12, 65.

MathuR, R. S. (1970) Histo-enzymological observations on spermatozoa of inbred strains of mice. 7. Reprod. Fert. $27,5$.

Williams, D. A., Beatty, R. A. \& Burgoyne, P. S. (1970) Multivariate analysis in the genetics of spermatozoan dimensions in mice. Proc. R. Soc. B, 175, 313.

'Worthington MANUAL'. (1969) Worthington Biochemical Corp., FreehoId, N.J., US.A. 